\title{
Understanding the crisis of refugee law: Legal scholarship and the EU asylum system
}

\author{
Rosemary Byrne ${ }^{1}$, Gregor Noll ${ }^{2}$ and Jens Vedsted-Hansen ${ }^{3}$ \\ ${ }^{1}$ Legal Studies, Social Science Division, New York University Abu Dhabi, PO Box 129188, Abu Dhabi, United Arab Emirates, \\ ${ }^{2}$ Department of Law, School of Business, Economics and Law, Box 650, SE 40530 Gothenburg, Sweden and ${ }^{3}$ Department of \\ Law, Aarhus University, Bartholins Allé 16, DK 8000 Aarhus C, Denmark \\ Email: Rosemary.Byrne@nyu.edu
}

\begin{abstract}
In 2015 Europe's refugee protection crisis triggered the effective collapse of the world's most complex regional framework for asylum. A development both unexpected and unexplained by the hierarchical model of European asylum law that tends to dominate the scholarly field. The abandonment among member states of core obligations under international and EU law and the principles of solidarity and good faith is central to this crisis. This dynamic has been in the making since the accession process when EU membership was offered in exchange for transposing international obligations through the EU asylum acquis, collectivizing external border control and shifting refugee 'responsibility' to new member states with minimal standards for refugee protection and weak enforcement mechanisms. Yet, the critical feature of this asylum crisis is its development into a European constitutional crisis, impacting freedom of movement, sincere co-operation, democracy, and the rule of law. A hierarchical model of law offers only a partial explanation of this interplay between refugee protection and European governance. A turn to the methodological debates in international law urges the repositioning of the lens of refugee legal scholarship, offering insights into the evolution towards crisis by looking at law from below against the backdrop of law in history, subregional law-making, and shifting power constellations. This process suggests that refugee law scholarship could benefit from widening its methodological canon by visiting its parent field of public international law.
\end{abstract}

Keywords: CEAS; EU constitutional principles; international law in history; refugee crisis; transnational law

\section{Introduction}

Having spent over 20 years identifying the fault lines in the construction of the Common European Asylum System (CEAS), one is reluctant to admit our failure to anticipate not only its effective collapse in the refugee crisis, ${ }^{1}$ but also that its breakdown would trigger a European constitutional crisis. The events of 2015 started as a crisis of protection for asylum seekers and refugees. Yet as the year unfolded, the effects of an inadequate asylum acquis also began to threaten the core tenets of European Union governance, impacting freedom of

${ }^{\star}$ The authors wish to thank Yao Xu for her excellent research assistance and our anonymous reviewers for their insightful comments.

${ }^{1}$ While this crisis is often referred to as the 'refugee crisis', we believe that the term 'asylum crisis' better reflects our focus on the structural failures of what was intended to be the Common European Asylum System (CEAS). As both terms are well established in discourse, we use them interchangeably. This does not imply an endorsement of the view that refugees themselves are ultimately to blame for the crisis.

(c) The Author(s), 2020. Published by Cambridge University Press. This is an Open Access article, distributed under the terms of the Creative Commons Attribution licence (http://creativecommons.org/licenses/by/4.0/), which permits unrestricted re-use, distribution, and reproduction in any medium, provided the original work is properly cited. 
movement, sincere co-operation, democracy, and the rule of law. The EU, the CEAS, and the relationship between diverse member states and forced migration introduce complex dynamics into the study of refugee protection that appear merely on the periphery when looking through the prism of formal international refugee law. This article argues that in order to more fully understand how protection and governance in Europe have been brought to the brink, there is a need for an expanded lens of inquiry. There is a growing literature that moves beyond the limits of the dominant positivist legal approaches in the field, turning to inter-disciplinarity. Scattered within this collection, there is a small body of research that draws from wider methodological trends in public international law. ${ }^{2}$ We propose that rather than looking to other disciplines, it is the richness of approaches to public international law that can widen inquiries within the field and offer important perspectives and insights. ${ }^{3}$

In the early 2000s, with refugee law colleagues in old and new member states, we studied how what was, and remains, the most extensive legal framework for refugee protection in the world was being gradually transposed onto the accession states in the Baltics and Central and Eastern Europe. Asylum governance had become one of the central preconditions for membership as the Union expanded from 15 to 25 and later 28 member states. In this process, refugee protection suddenly revealed itself as an exercise in the interplay between national, subregional, and regional law and policy-making processes. It became apparent that the mainstream approach of refugee lawyers on the continent that viewed the development of refugee law in new member states through the prism of the 'Brussels Diktat' did not capture the interactions between the candidate countries and their western neighbours. ${ }^{4}$ In hindsight, many of these dynamics foreshadowed the current resistance of new member states, in particular the Visegrád states, to EU asylum policy. ${ }^{5}$ Critically, the top-down approach of a refugee legal method did not sufficiently register the wider interactions within the EU, leaving unseen the capacity of a dysfunctional asylum system to trigger an unprecedented constitutional crisis.

The realities of formal law and often less visible state practice were also shaped then, as in the current crisis, by the dynamics of subregional interactions. To comprehend the factors that shape external border practices within an expanding Europe, we argued that one needed to look at the interactions between Berlin and Warsaw, Vienna, and Budapest, as much as consider the interplay between Brussels and the capitals of the new member states. ${ }^{6}$ In our contemporary context we have witnessed the reintroduction of border controls, whether between Germany and Austria, Austria and Hungary, Hungary and Croatia, France and Belgium, or Sweden and Denmark. These clearly have had a more immediate and often grave impact on state practice and refugee protection than any threat by the European Commission of infringement proceedings under EU law.

At the time of EU enlargement, however, deference to subregional and bilateral interactions between states was noted as a methodology adapted to the short term. This technique of exploring the reality of asylum policies was predicted to inevitably decline in significance as asylum harmonization took hold and the sequence of EU directives and regulations entered into force. In theory, a logical expectation as one now considers that there are close to 40 binding first- and secondgeneration EU legislative instruments related to migration and asylum with a potential impact on

\footnotetext{
${ }^{2}$ For an overview of approaches to refugee scholarship see R. Byrne and T. Gammeltoft-Hansen, 'International Refugee Law between Scholarship and Practice', (2020) 32(2) International Journal of Refugee Law 1. See also references in notes 72 to 77 below.

${ }^{3}$ Ibid.

${ }^{4}$ This was an argument we developed at length in R. Byrne, G. Noll and J. Vedsted-Hansen, 'Understanding Refugee Law in an Enlarged European Union', (2004) 15 European Journal of International Law 355.

${ }^{5} \mathrm{An}$ account of domestic implementation issues in the states acceding the Union in 2004, and the resulting challenges for the Union is offered in R. Byrne, G. Noll and J. Vedsted-Hansen (eds.), New Asylum Countries? Migration Control and Refugee Protection in an Enlarged European Union (2002).

${ }^{6}$ Byrne, Noll and Vedsted-Hansen, supra note 4, at 377-8.
} 
protection seekers. In practice, a less convincing explanation as actual conduct at the front line in transit and destination states exposed how the power of EU norms was heavily diluted.

This article explores the dual nature of the current crisis as one of asylum and of European constitutional governance and the ways in which both were foreshadowed in the accession process. More critically, it also asks which factors refugee legal scholars could have looked at in order to have anticipated more clearly their potential impact on refugee protection and asylum governance over time. We argue that refugee law scholarship should engage to a greater extent with international law in history and with transnational legal developments. As we will show in detail below, an examination of international law in the history of the cold war shows that, in Central and Eastern Europe, human rights were largely absorbed into the history of liberation from hegemonically imposed rule, while border control remained a remarkably constant factor that persevered during different epochs, rigidly linked to state survival. Also, in our account of the forces at play at the meta-level of European refugee law, we can show that low-level norms in the domestic domain start to resonate with high-level norms in the supranational and international domains - a type of analysis that is legal in character, but which traditional refugee law with its emphasis on top-down regulation denies us.

While the Baltic states were part of this EU enlargement process, it is the frontline role of the Visegrád states in the current refugee and constitutional crises that is the primary basis of our case study. Outside refugee law, there has been a vibrant expansion of how scholars think about how and why international law functions. We seek to expand the dialogue between refugee law and international law by identifying methodological alternatives that shed light on a range of phenomena that have marked this crisis. Section 2 explores how freedom of movement, sincere co-operation on refugee protection, and the democratic foundations of European politics all were simultaneously destabilized during the crisis. Section 3 shows that the post-2015 crisis can be traced back to the accession process and illustrates how the same constitutional dimensions freedom of movement, sincere co-operation, democracy - are central for an understanding of the failure of the protection ambitions of the transposed asylum acquis. Section 4 concludes with a discussion of three core factors that emerge from our cross-cutting analysis of the 2015 crisis: an EU protection architecture tilting towards border control; unequal effects of EU asylum law on core and peripheral member states, and an emerging populist scepticism towards Brussels and the promise of European 'solidarity' for the reception of refugees. Critically, each of these dynamics were present, to different degrees, in the early days of the accession process in the 1990s. Section 5 reflects on the implications our analysis has for the methodological development of refugee law. Instead of relying on a hierarchical model of law alone - whose focus is on checking the conformity of lower-ranking norms or practices with higher-ranking norms - refugee lawyers should place their field of international law in history, focus on subregionalism as part of the transnational approach to law, and consider how law is experienced when imposed from core to peripheral states. In doing that, we propose to adapt the select dynamics captured in Third World Approaches to International Law (TWAIL) to the experience of the new member states within the EU. This, we believe, offers a more layered appreciation of how international and regional refugee law has struggled to deliver the protection it promises.

\section{Europe's constitutional and asylum crisis}

When Bauböck regretted 'the blocking of European solutions by unwilling Member States who are ready to sacrifice European integration because they are not ready to accept their duties towards refugees', he was observing how the 2015 crisis spilled over into the foundations of European governance. ${ }^{7}$ International refugee law is governed by the 1951 Convention, whereas the EU asylum acquis remains merely a regional legal construct, yet one that has direct effect on protection

${ }^{7}$ R. Bauböck, 'Europe's commitments and failures in the refugee crisis', (2018) 17 European Political Science 140. 
seekers throughout the 28 member states. ${ }^{8}$ Within this context, the hierarchical approach of refugee legal scholarship directs our attention to the interplay between international and EU protection obligations and member state practices on the ground towards asylum seekers. This section widens the lens to examine how the arrival of migrants and refugees in 2015 intersected with EU governance, striking at the fundamental right of freedom of movement of EU citizens, the core obligation of sincere co-operation towards other member states, and the EU principles of democracy and the rule of law. The Visegrád states, finding themselves confronted with the consequences of fulfilling 'European' refugee obligations, in turn instrumentalized and subverted the Brussels norms, while pursuing parallel strategies with neighbouring member states. This strategy was closely observed and exploited by domestic political processes across subregions. The ways in which the EU asylum acquis unravelled in 2015-2016, discussed below, echo some of the dynamics in play in Central and Eastern Europe during the accession process into the EU a decade earlier, which will be the focus of Section 3.

\subsection{Freedom of movement and external borders}

The reintroduction of internal border controls by Schengen states remains the defining feature of the refugee crisis. Beyond signalling a heightened political fear of uncontrolled migrant arrivals, it reflects a disengagement with the EU asylum acquis, as states sought to work within, around and against EU and international law to insulate themselves from the effects of the asylum crisis. This practice of leaving refugees to remain in neighbouring states was legitimated by the concept of 'protection elsewhere' in international refugee law, that B. S. Chimni observed took hold in the Global North from the 1980s onwards. ${ }^{9}$ Germany's closure of its borders to neighbouring Austria on 13 September 2015 was followed in rapid succession by those of its neighbour Austria and then, in turn, by Austria's neighbour Slovenia, and, in October 2015, by Slovenia's neighbour Hungary. ${ }^{10}$ Two months later, a similar domino reaction took effect at Scandinavia's borders. After Sweden announced the closure of its borders in December 2015, border closures were announced by Norway, and in January 2016 by Denmark. Today, borders between strategically placed member states remain at the centre of European politics.

While France and Malta announced the closure of borders on account of terrorism, after September 2015 the expanding number of states closing borders announced the closures on the grounds of a 'big influx of migrants' or an 'unexpected migratory flow'. ${ }^{11}$ These flows, both actual and anticipated, reflected a rise in secondary movements of asylum seekers from the frontline receiving member states stemming from a deeper dysfunction of the EU asylum acquis. Responsibility for asylum seekers within the EU is legally relegated to the frontline member states under the Dublin Regulation. ${ }^{12}$ The burden resulting from inequitable distribution under the Dublin Regulation was, in theory, to be shouldered by a solidarity amongst other member states

\footnotetext{
${ }^{8}$ See CJEU Judgment of 14 May 2019, Joined Cases C-391/16, C-77/17 and C-78/17, M v. Ministerstvo vnitra and X and Xv. Commissaire general aux réfugiés et aux apatrides (ECLI:EU:C:2019:403). See also Advocate General's Opinion of 21 June 2018 (ECLI:EU:C:2018:486).

${ }^{9}$ B. S. Chimni, 'The Geopolitics of Refugee Studies: A View from the South', (1998) 11 Journal of Refugee Studies 350.

${ }^{10}$ Originally, the German government had decided to close its borders to any migrant without proper documents, including asylum seekers. It backed away from this harsher position as the government was advised that this would be illegal. On 13 September 2015, the border to Austria was closed for all migrants without the proper documents, with an exception made for asylum seekers, see www.dw.com/en/report-germany-planned-to-close-border-at-height-of-2015-refugee-crisis/a-37817614.

${ }^{11}$ E. Guild, E. Brouwer and K. Groenendijk (eds.), Internal borders in the Schengen area: Is Schengen crisis proof?, at 15, available at www.europarl.europa.eu/RegData/etudes/STUD/2016/571356/IPOL_STU\%282016\%29571356_EN.pdf.

${ }^{12}$ The responsibility sharing system under the 1990 Dublin Convention (OJ 1997 C 254/1) was subsequently incorporated into EU law by the Dublin Regulation, currently Regulation No. 604/2013 establishing the criteria and mechanisms for determining the Member State responsible for examining an application for international protection lodged in one of the Member States by a third-country national or a stateless person (recast), OJ 2013 L 180/31 (hereinafter Dublin III)
} 
relocating their quota of asylum seekers assigned by Council Decisions in $2015 .{ }^{13}$ In spite of the growing flow of secondary movements, the Dublin Regulation was irrelevant for most EU member states of first arrival as asylum seekers continued to move irregularly to their preferred destination member state. Except for Sweden and Germany, few states were taking credible measures to relocate asylum seekers in early 2015. The rise of secondary movements that triggered the border closures and controls was also encouraged by the desire to seek asylum in member states where applicants would experience better reception conditions and prospects for their future. By 2018, Germany, one of the staunchest supporters of the Dublin system, started to draw up an alternative web of bilateral readmission agreements, starting with Spain and Greece. ${ }^{14}$ This retreat from multilateralism to bilateralism enabled a few member states to derail the agreed order of the majority.

For many observers, the reintroduction of border controls signalled an ominous threat to the freedom of movement, one of the four fundamental freedoms enshrined in the 1957 Treaty of Rome. ${ }^{15}$ Freedom of movement is part of the foundational narrative of the European Union, and the opening of borders with the 1985 Schengen Agreement and the 1990 implementing Convention eliminated border controls was one of the most visible and critical mechanisms taken to ensure its enjoyment by EU citizens. ${ }^{16}$ Schengen's centrality to the EU was acknowledged by the European Commission President Jean-Claude Juncker who warned ' . . . whoever kills Schengen brings the internal market to its grave'. ${ }^{17}$ Border controls seeking to stem migrant arrivals did not stop EU citizens from exercising their freedom of movement rights per se. Yet for European citizens and commercial enterprises daily dependant on expedient passage across frontiers within the Schengen zone, lengthy waits at border crossings clearly impact the quality of how the right to freedom of movement is exercised. ${ }^{18}$

As the European Commission observed in 2016 in its 'Road Map Back to Schengen', the Area was 'one of the major achievements of European integration'. ${ }^{19}$ From the vantage point of Brussels, Schengen was 'shaken to the core' when member states began to announce temporary border closures in 2015, some controls that have extended through to the present in 2019. The free circulation of persons across borders was a key way for European citizens to exercise their freedoms. ${ }^{20}$ In the realm of immigration policies more broadly, the practice of states mirroring

\footnotetext{
${ }^{13}$ Council Decision (EU) 2015/1523 of 14 September 2015 establishing provisional measures in the area of international protection for the benefit of Italy and Greece, OJ 2015 L 239/146, and Council Decision (EU) 2015/1601 of 22 September 2015 establishing provisional measures in the area of international protection for the benefit of Italy and Greece, OJ 2015 L 248/80; cf. CJEU Judgment of 6 September 2017, Joined Cases C-643/15 and C-647/15, Slovak Republic and Hungary v. Council of the European Union (ECLI:EU:C:2017:631) concerning the legality of the latter Decision; CJEU judgment of 2 April 2020, Joined Cases C-715/17, C-718/17 and C-719/17, European Commission v. Republic of Poland, Hungary and Czech Republic (ECLI:EU:C:2020:257). For possible future relocation arrangements see Commission proposal of 4 May 2016 for a recast Dublin Regulation, COM(2016) 270 final, Arts. 34-43, and Commission Communication of 7 December 2017, COM(2017) 820 final, at 4-6.

${ }^{14}$ See P. Slominski and F. Trauner, 'How Do Member States Return Unwanted Migrants? The Strategic (non-) use of "Europe” during the Migration Crisis', (2018) 56 Journal of Common Market Studies 101.

${ }^{15}$ Art. 48, 1957 Treaty of Rome, Art. 3(2) of the 2012 Treaty on European Union (TEU) C 326/13; Arts. 4(2)(a), 20, 26, and 45-48 of the Treaty on the Functioning of the European Union (TFEU)

${ }^{16}$ The 26 state members of the Schengen Area include four non-EU states: Iceland, Lichtenstein, Norway, and Switzerland. The United Kingdom and Ireland opted out. Once Romania, Bulgaria, Cyprus, and Croatia fulfil the technical requirements of entry, the Schengen Area will include all other member states.

${ }^{17}$ D. Scally, S. Lynch and R. Mac Cormaic, 'EU could fail if refugee crisis is not tackled, Juncker says', Irish Times, 16 January 2016, available at www.irishtimes.com/news/world/europe/eu-could-fail-if-refugee-crisis-is-not-tackled-juncker-says-1.2498819.

${ }^{18}$ It is notable that it is the threat of a hard border between Northern Ireland and Ireland that has been a central barrier to a Brexit agreement. It raises issues similar to the border controls within Schengen as a hard border would not prevent citizens, North and South, from crossing the border. The delays it would create, however, would lead to serious disruption for citizens and cross border businesses.

${ }^{19}$ European Commission, Communication from the Commission to the European Parliament, the European Council and the Council: Back to Schengen - A Roadmap, 4 March 2016, COM(2016) 120 final.

${ }^{20} \mathrm{Tbid}$.
} 
the laws in other jurisdictions is a familiar phenomenon, whether it be between Brazil and Argentina, Ecuador and Chile, Australia and the United Kingdom, or as was witnessed in the 2000s between the Visegrád states and the old member states. ${ }^{21}$ It was the rapid onset of the 2015-2016 member state chain border closures that shocked governments and European policymakers. The situation in early 2016, as described by the European Council on Foreign Relations, 'would have been unthinkable six months earlier'. ${ }^{22}$ The costs to states, businesses, and citizens of the end of free circulation in the Schengen Area were estimated to fall between five and 18 billion euros. $^{23}$

The corollary of free movement of people and goods across member states was a fortified external border. ${ }^{24}$ Its physical fortification is now escalated through the introduction of modern surveillance technology and the construction of fences along the perimeter of frontier member states. It also involved a range of what became known as non-entrée policies, such as EU visa and carrier sanctions legislation that prevented refugees from arriving in Europe to seek protection. The concept of 'protection elsewhere' was a sanitizing doctrine that, in principle, offered a means of shifting responsibility for the assessment of asylum claims to transit countries. As explored in Section 4, in the European Union this role was to be assumed by the Visegrád states and their eastern neighbours. Although a crude representation for the complex legal regime governing migration, 'Fortress Europe' became the dominant metaphor for the effects of Europe's fortification of external borders.

Casting the construction of restrictive immigration and refugee legislation in terms of 'Fortress Europe' did not reflect the post-2012 reality at the borders of the EU. With over 1,000,000 migrants entering Europe largely via the Mediterranean Sea in 2015, if Europe was a 'fortress', its walls were particularly porous. While most member states proved unwilling to relocate asylum seekers once they had arrived in Europe, along with the creation of 'hot spots' and the support for the work of the European Asylum Support Agency (EASO) they supported the expansion of the EU border agency, Frontex, and the transfer of surveillance technology and border control expertise to the frontline states. The symbolism of the expensive measures to seal external borders lent support to those inclined to view refugees as illegal migrants. Through agreements with Turkey, Libya, and other MENA states, the EU attempted to construct migration buffer zones. ${ }^{25}$ Alongside the collective approach through multilateral 'deals' with transit states, individual member states took matters in their own hands, with a proliferation of bilateral 'co-operation' arrangements with third countries. ${ }^{26}$

Peter Slominski and Florian Trauner observe the tradition in migration of member states going 'multilateral' to undermine the collective efforts of the EU. By passing the EU external policy framework, this process accelerated during the crisis. For instance, in February 2016, Austria and its neighbour Slovenia negotiated the closure of the Macedonian/Greek border and shut down

\footnotetext{
${ }^{21}$ See D. Cook-Martín and D. FitzGerald, 'Liberalism and the Limits of Inclusion: Race and Immigration Law in the Americas 1850-2000', (2010) 41 Journal of Interdisciplinary History 7; A. S. Timmer and J. G. Williamson, 'Immigration policy prior to the 1930s: Labor markets, policy interactions, and globalization backlash', (1998) 24 Population and Development Review 739.

${ }^{22}$ European Council of Foreign Relations, The Future of Schengen (2016), available at www.ecfr.eu/specials/scorecard/ schengen_flash_scorecard.

${ }^{23}$ Ibid., at 3-4.

${ }^{24}$ The political packaging of internal freedom of movement with external immobilization has been an important part of the history of the EU, yet it is often overlooked. By the mid-1950s, France made clear that it wished to join a Common Market only in conjunction with its overseas countries and territories. As it saw population movements between those and European countries as problematic, these were to be excluded from any freedom of movement. Other negotiating parties followed suit. P. Hansen and S. Jonsson, Eurafrica. The Untold History of European Integration and Colonialism (2014), at 150-1.

${ }^{25}$ See European Council, EU-Turkey Statement, 18 March 2016, available at www.consilium.europa.eu/en/press/pressreleases/2016/03/18-eu-turkey-statement/.

${ }^{26}$ Association for Juridical Studies on Immigration, Italy - Libya agreement: Memorandum of Understanding (2017), available at www.asgi.it/wp-content/uploads/2017/02/ITALY-LIBYA-MEMORANDUM-02.02.2017.pdf; see Slominski and Trauner, supra note 14 , at 111 .
} 
the Western Balkan migration route. Other member states, through the backdoor of linkages between returns and development aid and co-operation agreements, entered into bilateral agreements with sending and transit states, as Germany did with Algeria, Morocco, and Tunisia. ${ }^{27}$

The weakening of the EU's 'fortress' occurred in tandem with the Syrian civil war and the shift from travel routes into Europe through the green land borders of the East and South of Europe to the more perilous crossing of the Mediterranean. The number of protection seekers peaked in 2015 although the mortality rates of crossing the Mediterranean were to continue to climb. According to the International Organization for Migration (IOM), Europe is a leader in migrant deaths. There was a delayed awareness of this phenomenon within the EU and beyond as the first official IOM global count of migrant deaths did not occur until 2014. The organization estimates that 40,000 migrants had lost their lives globally since 2000 - 22,000 within Europe - and concedes that these numbers are likely much higher given the impossibility of tracing many deaths. Patterns of shifting migrant routes that responded to border practices were evident at the time. In 2004, migration researchers understood well that there were unregistered human costs that occurred in the 'grey' invisible zones of migration where conventional and safer means of travel increasingly became replaced by riskier clandestine journeys. There was a recognition then of the symbiotic relationship between tightening border controls and fostering the criminal exploitation of those driven to pay smugglers in order to enter into Europe. Yet, it was not fully anticipated how the toll of human life and suffering would escalate to an unprecedented degree when this phenomenon was transposed onto another more lethal migratory route with the shift from green to blue borders. And neither was it clear that the European system had a breaking point where a particular number of protection seekers would reveal its limited capacity or political will - pulling down free movement in its fall.

Refugee lawyers did not anticipate single member states reacting to this constitutional crisis by resorting to domestic border controls rather than investing their efforts in a reformed EU system. This suggests a deeper distrust of international and regional legal obligations by elected governments as frontiers with subregional neighbours and the impact on local communities carried more persuasive power than the provisions of a past and future asylum acquis.

\subsection{Burden-shifting trumps sincere co-operation and solidarity}

The CEAS was the world's most developed regional legal framework for refugee protection, and in the 2015 refugee crisis it came close to collapse. Underlying the CEAS was a matrix of legal obligations that member states owed not simply to individual asylum seekers, but to each other. The 'protection elsewhere' concept vested the acquis with a co-operative system of redistribution of responsibility for asylum seekers under the Dublin Convention and later Dublin Regulations. The disdain for EU law exhibited at moments in the respective statements of the Visegrád states during this crisis displayed a cynicism about the proclaimed principle of 'solidarity' and its beneficiaries along with the process of Brussels law-making. While the history of international refugee law is shaped by the failure of states to fulfil their obligations towards protection seekers, the most striking feature of Europe's crisis is that it was arguably the failure of member states to respect obligations owed to each other that precipitated the erosion of the regional asylum system.

The 'general application' duty of 'sincere co-operation' is enshrined in Article 4(3) TEU and requires member states to assist each other in carrying out the obligations of the Treaties of the European Union. ${ }^{28}$ The 2015 refugee reception crisis is a narrative about the absence of sincere co-operation as good faith compliance with the CEAS, including the Dublin regime, and with

\footnotetext{
${ }^{27}$ See Slominski and Trauner, ibid.

${ }^{28}$ Art. 4(3) TEU: 'Pursuant to the principle of sincere cooperation, the Union and the Member States shall, in full mutual respect, assist each other in carrying out tasks which flow from the Treaties. The Member States shall take any appropriate measure, general or particular, to ensure fulfilment of the obligations arising out of the Treaties ....'.
} 
central norms of the Schengen acquis. In reasserting national control over their borders, the select Schengen states opted for a non-co-operative solution that would address their national policy agenda to prevent the spontaneous arrival of asylum seekers within their territory. This was one of the many ways that both frontline and more geographically remote member states engaged in 'self-help'.

The preferred language of refugee policy taught us to replace 'burden sharing' with 'responsibility sharing' in international legal discourse. This semantic exercise hardly concealed the agenda of the 'protection elsewhere' practices or the 'responsibility' allocation system of the Dublin regime that was noted first and foremost amongst observers to be a mechanism for 'burden shifting' to the frontline states, including the Visegrád Four. As much as 'burden shifting' remains fundamental to the cynical design of the Dublin regime, this crisis is about the consequence of 'burden resisting'. All of the academic literature commenting on the Dublin system in its original and subsequent legislative forms rightly identified the very real protection risks involved in returning asylum seekers to member states with weak refugee protection regimes. What refugee law scholars and activists did not anticipate was that the Dublin system itself would not be effective enough to return more than a negligible number of asylum seekers to frontline states. ${ }^{29}$ The reform of the Dublin III Regulation occurred against the backdrop of the extreme inefficiency of the system, with only 3-4 per cent of applications lodged in the Dublin area resulting in Dublin transfers. ${ }^{30}$ 'Burden resisting' by these frontline states - another expression of self-help - translated into a systematic failure to register asylum seekers and a pattern of 'wave throughs' at border posts. In spite of the comparatively marginal power that frontline states had within the European Union, they had the ability to subvert the Dublin system.

Relations between member states as regards borders, immigration and asylum are governed by the principle of solidarity and fair sharing, laid down in Article 80 TFEU. The 2001 Temporary Protection Directive recasts core principles for protection in Europe by offering group-based protection that would free receiving states from a long-term commitment towards hosting refugees. ${ }^{31}$ While it was feared that the temporal limitation on protection would mark the downgrading of the 1951 Convention rights, the solidarity provisions manifested in the TP Directive seemed a credible crisis instrument premised on member state co-operation and equitable responsibility sharing. Yet, the crucial Council decision necessary to trigger the obligations of the TP Directive would ensure that it would remain dead letter. When in 2011, the strain in reception, status determination, and rescue capacities led Italy and Malta to request the Commission to act, a proposal to trigger the TP Directive was not even made to the Council. ${ }^{32}$

In September 2015, the EU Emergency Relocation Scheme created an alternative form of responsibility sharing through quotas for the relocation of protection seekers from Italy and Greece. ${ }^{33}$ The first Decision proposed the relocation of 40,000 individuals, the second 120,000. In its April 2017 report on relocation and resettlement, the Commission observes that in spite of a progressive increase in the pace of relocations by member states, it represents less than

\footnotetext{
${ }^{29}$ The Dublin Regulation is applied by all EU member states and Norway, Iceland, Switzerland, and Liechtenstein.

${ }^{30}$ F. Maiani, 'The Reform of the Dublin III Regulation', Study PE 571.360 (2016), at 15-16, available at www.europarl. europa.eu/RegData/etudes/STUD/2016/571360/IPOL_STU(2016)571360_EN.pdf.

${ }^{31}$ Council Directive 2001/55/EC of 20 July 2001 on minimum standards for giving temporary protection in the event of a mass influx of displaced persons and on measures promoting a balance of efforts between Member States in receiving such persons and bearing the consequences thereof, OJ 2001 L 212/12 (hereinafter TP Directive).

${ }^{32}$ European Commission, Study on Temporary Protection Directive: Final Report (2016), available at ec.europa.eu/homeaffairs/sites/homeaffairs/files/e-library/documents/policies/asylum/temporary-protection/docs/final_report_evaluation_tpd_en. pdf; see also M. Garlick, Solidarity under Strain: Solidarity and Fair Sharing of Responsibility in Law and Practice for the International Protection of Refugees in the European Union (2016) (Radboud University Nijmegen, PhD thesis).

${ }^{33}$ See supra note 13 .
} 
8 per cent of the legal obligation so far allocated by the Council. ${ }^{34}$ When the Scheme concluded in March 2018, the Commission reported that all of 34,000 persons had been relocated out of the initial quota commitment of 160,000 . The eligibility criteria were controversial, whereby asylum seekers could only qualify for relocation if they were from a country of origin from which 75 per cent or more of applicants had been granted international protection across EU member states. The criteria, however, also allowed the Commission to declare that 96 per cent of all eligible applicants 'registered' had been relocated, ${ }^{35}$ permitting cosmetic claims of sincere co-operation and solidarity amongst member states. Nonetheless, layered legal instruments directing member states to share and shoulder responsibility for asylum seekers were ultimately subverted by national political priorities.

Confronted with the effects of the failed solidarity of member states, the incentives to undermine the co-operative and inequitable Dublin framework were strong. The subversion of Dublin generated the secondary movements that brought Schengen to the brink. Neither the CEAS nor the Commission, nor the Court of Justice of the European Union (CJEU), nor the European Court of Human Rights (ECtHR) could compel states to share the 'responsibility' of frontline states hosting refugees. However, the ECtHR judgment in M.S.S. v. Belgium and Greece and the CJEU ruling in N.S. and M.E. illustrate the extent to which failed solidarity generates perverse incentives for frontline states. The judgments held that a member state could not be 'unaware' of the deficiencies in the Greek asylum system that gave rise to a 'real risk' that asylum seekers returned to Greece would be subject to inhuman or degrading treatment in violation of Article 3 ECHR as well as the EU Charter. ${ }^{36}$ This provides an excellent example of how the top-down application of human rights protects refugees. It is worth shifting our perspectives, however, to acknowledge a wider framework of dynamics affecting the threshold of protection provided by Greece as a frontline state. The legal duties of sincere co-operation and solidarity did not solve the problem of the unfair regional responsibility for asylum seekers that Greece shoulders. Yet, inhumane conditions and a subsequent condemnation by Europe's leading court, at least in the short term, prevented the returns of asylum seekers that had moved irregularly through the EU. Determining the motivations of actors within the Greek government is outside the scope of our legal competence. While these cases defended human rights, it warrants considering the implications for Greece of compliance with human rights and refugee protection standards on secondary migration and Member State solidarity. Regardless of the intent of the Greek government in its treatment of protection seekers, it is clear that the EU system has created perverse incentives for frontline states to continue to violate international and regional obligations towards refugees in order to avoid responsibility under the Dublin sharing mechanism.

\subsection{Illiberal democracy and the rule of law}

Asylum in Europe is experiencing a crisis of politics, not simply of law. Pluralism and the rule of law are fundamental values of Europe, and the principle of democracy has been part of primary

\footnotetext{
${ }^{34}$ European Commission, Tenth report on relocation and resettlement, 2 March 2017, COM(2017) 202 available at ec. europa.eu/home-affairs/sites/homeaffairs/files/what-we-do/policies/european-agenda-migration/20170302_tenth_report_on_ relocation_and_resettlement_en.pdf; see also E. Karageorgiou, 'Rethinking Solidarity in European Asylum Law: A Critical Reading of the Key Concept in Contemporary Refugee Policy' (2018) (Lund University, PhD thesis); M. Garlick, 'Solidarity under Strain: Solidarity and Fair Sharing of Responsibility in Law and Practice for the International Protection of Refugees in the European Union' (2016) (Radboud University Nijmegen, PhD thesis).

${ }^{35}$ European Commission, European Agenda on Migration: Continuous efforts needed to sustain progress, 14 March 2018 , available at europa.eu/rapid/press-release_IP-18-1763_en.htm.

${ }^{36}$ M.S.S. v. Belgium and Greece, Appl. No. 30696/09, GC Judgment of 21 January 2011; CJEU Judgment of 21 December 2011, Joined Cases C-411/10 and C-493/10, N.S. v. Secretary of State for the Home Department and M.E. and Others v. Minister for Justice, Equality and Law Reform, (ECLI:EU:C:2011:865).
} 
EU law since its inclusion into Article F of the Maastricht Treaty. ${ }^{37}$ To the extent that Europe is in the midst of a democratic crisis, it is usually associated with the rise of populism across the continent. The region was also recovering from the fallout of the 2008 financial and economic crises, with many member states experiencing rising unemployment, declining standards of living and state budget cuts. ${ }^{38}$ As Jan-Werner Müller points out, while populism might be seen as an 'emancipatory participation of "the people"', the political project itself that lays claims to representing a monolithic people clashes with conceptions of democratic pluralism. ${ }^{39}$ The inter-relationship between the refugee and national democratic crises across member states calls for a complex analysis which falls outside the scope of this article. However, it is welldocumented that the opposition to protection seekers and migrants occurred in tandem with the rapid rise of populist parties in some member states that have scapegoated refugees along with immigrant communities and other religious and ethnic minorities. ${ }^{40} \mathrm{With}$ the electoral success that installed Fidesz three times into power in Hungary and the Law and Justice Party in Poland, both governments began the dismantling of the independence of their respective judiciaries. ${ }^{41}$ Their brand of nationalism often envisions a zero sum game between the human rights of migrants, and national identity and security. Immediately after Fidesz's 2018 electoral victory, one of the first attacks launched by the triumphant Orbán regime was to pass what became known as the 'Stop Soros Law' that criminalized unpatriotic assistance to asylum seekers, targeting civil society organizations doing front line protection work, such as the Hungarian Helsinki Committee. ${ }^{42}$

Alongside xenophobic and nativist undercurrents that characterize strands of the western European populism, there is a strong antipathy towards elites and the international legal obligations that they promote. ${ }^{43}$ This is especially pronounced with regard to international and EU actors. Some politicians eagerly exploited the opportunity to frame the refugee crisis as one that EU law and Brussels inflicted upon receiving member states. ${ }^{44}$ The hostility towards regional legal obligations runs counter to early prevailing assumptions of EU refugee lawyers about the potential of the CEAS that was being transposed onto the accession states by Brussels bureaucrats and national elites. The belief was that the varied and often problematic protection dynamics at the local and subregional levels would be improved and gradually be overtaken by the expanded and deepened European Union. ${ }^{45}$ This perspective was not unique to EU refugee lawyers. The view that the focal points for understanding refugee law would shift along with the evolution of regional governance was shared by social scientists looking at the locus of conflicts around migration issues in the 1990s. The transformations brought on by globalization gave rise to claims that a shift would occur from contestations taking place on the national level to those happening in the supranational arena, with the former diminishing in importance. Nonetheless, there is

\footnotetext{
${ }^{37}$ Today, the principle informs Arts. 9-12 TEU. For an argument that the Treaty of Maastricht has effectively put the EU on a democratic course and that the CJEU supports the principle of democracy in its case law, see K. Lenaerts, 'The Principle of Democracy in the Case Law of the European Court of Justice', (2013) 62 International and Comparative Law Quarterly 271.

${ }^{38}$ See F. Trauner, 'Asylum policy: The EU's “crises" and the looming policy regime failure', (2016) 38 Journal of European Integration 311.

${ }^{39}$ J.-W. Müller, What Is Populism? (2016), at 20-4.

${ }^{40} \mathrm{C}$. Postelnicescu, 'Europe's New Identity: The Refugee Crisis and the Rise of Nationalism', (2016) 12 Europe's Journal of Psychology 203; Human Rights Watch, 'The Dangerous Rise of Populism: Global Attacks on Human Rights Values', 2017, available at perma.cc/W9YS-PBY3.

${ }^{41}$ See CJEU Judgment of 24 June 2019, Case C-619/18, Commission v. Poland (Indépendance de la Cour suprême) (ECLI:EU: C:2019:531).

${ }^{42}$ Criminal Code [Hungary], Act C of 2012, S353/A 2012, available at www.refworld.org/docid/4c358dd22.html; 'On World Refugee Day Hungary Makes it Illegal to Help Refugees and Migrants', Open Society Foundations, 20 June 2018, available at www.opensocietyfoundations.org/press-releases/world-refugee-day-hungary-makes-it-illegal-help-refugees-and-migrants.

${ }^{43}$ See B. Eichengreen, The Populist Temptation: Economic Grievance And Political Reaction in the Modern Era (2018), 1; F. V. Perry, The Assault on International Law: Populism and Entropy on The March, 46 Syracuse J. Int'l L. \& Com. 59, at 62-3.

${ }^{44}$ R. Byrne, 'Refugee Advocacy Scholarship', (2019) 8 Canadian Journal of Human Rights Law 103, at 146-7.

${ }^{45}$ Byrne, Noll and Vedsted-Hansen, supra note 4, at 356, fn 2.
} 
substantial evidence that the core of political debates and mobilizations on immigration were to remain anchored to the national level. ${ }^{46}$

Just as populism was largely dismissed in the East prior to the current crisis, the rise of populism in the West was ignored, both with implications for refugee protection. The presence of populist actors on the main political stage left more centrist candidates appropriating anti-immigrant rhetoric in campaign proclamations, normalizing the extremes of political discourse. By way of example, German Interior Minister Seehofer pressured Chancellor Merkel during 2018 to switch from common European solutions to the bilateral conclusion of readmission agreements. Seehofer's objective was to claim back the political space that was held by the hard nationalist Alternative für Deutschland (AfD) party after their entry into the German parliament. Populist success is a main factor in bringing about a renationalization and bilateralization of refugee law and politics.

This takes us back to a stage in the legal evolution of EU asylum law that was staunchly international rather than supranational and driven by hegemonic norm entrepreneurs among member states. The 1990s of the Dublin and Schengen Conventions and the non-binding London Resolutions of 1992 adopted by the Ministers of the member states of the European Communities. Unlike today's system of supranational EU law, this law manifested the capacity to accommodate the recalcitrance of single states without harming the integrity of the legal system itself. The experience of the crisis of 2015, embedded within the web of EU treaties, directives, and regulations, suggests that integrity of supranational law is more susceptible to harm when states object or subvert its constituent instruments.

\subsection{Conclusion}

In this section, we have described a constitutional crisis that is entwined with a deeper disregard by member states of the architecture of European refugee protection. The force of EU law that was assumed to be an agent of transformation evolved into a focal point for resistance. It is both regional and subregional burden resistance strategies that have triggered a symbiotic unfolding of Europe's refugee and constitutional crises. For the Visegrád states, the concept of 'protection elsewhere' surfaced as the underlying target of governments. In practice, the concept arguably offers the most graphic representation of how international legal norms can be tailored to achieve the desired ends of core states at the expense of presumed 'norm taker' states at the periphery. The cost of not anticipating the interplay between refugee law and resistance has been the constitutional crisis that challenges the future of Europe.

\section{Accession and the making of today's crises}

The CEAS developments provide an exemplary illustration of the transnational approach that may usefully contribute to explaining the asylum crisis, as further elaborated in Sections 4 and 5 below, pointing to the relevance of focusing on history and power imbalances. The incomplete transposition and inefficient implementation of core standards on protection of asylum seekers and refugees are generic to the problem of failure in the duty of sincere co-operation among EU member states, proclaimed in Article 4(3) TEU, and at the same time specific to the regulatory crisis of the CEAS. This section attempts to explain the latter by drawing attention to the reluctance of new member states towards the CEAS standards and its historical background in the accession process. Next, we shall demonstrate how this is to be seen in the wider context of the regulatory incentives inherent in the CEAS structure, which during the asylum crisis fostered

\footnotetext{
${ }^{46}$ N. Eggert and M. Giugni, 'Migration and Social Movements', in D. Della Porta et al. (eds.), The Oxford Handbook of Social Movements (2015), 159, at 165-6.
} 
scepticism, reluctance and ultimately resistance within the new member states, most significantly the Visegrád states.

\subsection{Freedom of movement in exchange for external border control}

In the area of free movement of persons, EU membership is about bartering internal free movement against the reinforcement of external borders. In the process of preparation for the EU enlargements in 2004 and 2007, the borders that would separate the new member states from their non-EU neighbours were a central issue in negotiations. Refugee protection was to be seen as a necessary corollary to the exercise of external border control that would be entrusted to the new member states. ${ }^{47}$ The historical legacy of the Central European and Baltic states potentially subordinated human rights and protection obligations to concerns over sovereignty, border control and state survival. This is likely to have significantly impacted on the framing of their normative approach to protection issues. None of these new member states had been parties to the Refugee Convention or the ECHR during the period of communist regimes. ${ }^{48}$

At that time, the negative inclination towards individually held human rights was an outflow of their dependency on the Soviet Union. Border control, on the other hand, had been an issue of economic survival for the command economies of the East and part of the tutelage of the Soviet government. To 'protect the peaceful labours of their peoples, guarantee the inviolability of their frontiers and territories' was part of collective security obligations under Article 5 of the 1955 Warsaw Pact. ${ }^{49}$ By way of illustration, the communist seizure of power in Czechoslovakia led to a massive outflow of citizens towards the West. Authorities countered with the fortification of borders and the use of force against trespassers. At no time in their history after the Second World War did the standards governing such border management force a fleeing population of non-nationals onto Central European or Baltic states' territory for more than a transitory period. ${ }^{50}$ The generation of politicians negotiating EU accession had personally lived in regimes applying draconian border control qua the Warsaw Pact co-operation, but lacked historical references to internationally co-ordinated refugee reception on their territory.

Against that background, committing themselves under international refugee and human rights law to offer protection to asylum seekers and refugees as a precondition for EU accession and the ensuing free movement of the citizens of the new member states is likely to have influenced the perception of these protection standards as more of a formal than a real undertaking. Such elements of conditionality or even pressure to accede to the Refugee Convention were not necessarily reflecting genuine and principled commitment to the historical foundations of the refugee protection regime as understood in Western Europe. Despite the general support for human rights and the rule of law as an integral part of taking issue with the past regimes under Soviet dominance, this did not necessarily result in unequivocal popular and institutional support of these foundations and their protective implications in situations of migrant and refugee arrivals.

\footnotetext{
${ }^{47}$ Cf. Byrne, Noll and Vedsted-Hansen, supra note 4, at 368-9.

${ }^{48}$ We here leave aside Hungary's accession to the 1951 Refugee Convention in March 1989 due to the specific situation following the arrival of people from the Hungarian minority in Romania.

${ }^{49}$ Treaty of Friendship, Cooperation and Mutual Assistance Between the People's Republic of Albania, the People's Republic of Bulgaria, the Hungarian People's Republic, the German Democratic Republic, the Polish People's Republic, the Rumanian People's Republic, the Union of Soviet Socialist Republics and the Czechoslovak Republic, 14 May 1955, New Times, No. 21, May 21, 1955, pp. 65-67. Unofficial English translations are available at avalon.law.yale.edu/ 20th_century/warsaw.asp or germanhistorydocs.ghi-dc.org/pdf/eng/Security\%209\%20Warsaw\%20ENG.pdf.

${ }^{50}$ Thousands of citizens of the German Democratic Republic fled to the Prague Embassy of the Federal Republic of Germany in September 1989 in the hope of their exit towards the Federal Republic of Germany being negotiated. Which happened with the Germans departing. Together with the opening of the Czech-Austrian border, it marked the beginning of the end of Cold War border enforcement.
} 
The multilateral pre-accession process as well as the subregional interactions in the context of border control policy and practice may have corroborated this pre-understanding within legislative, administrative and possibly even some of the judicial bodies of migration control governance in the new member states. ${ }^{51}$ In particular, capacity building was so central to these processes that it must have become clear during the pre-accession process that these states were supposed to develop themselves into buffer states on the eastern periphery of the old EU member states. Indeed, one of the primary objectives in requiring the implementation by candidate states of the first phase of the asylum acquis was the enlargement of the 'pool of potential third countries' to which asylum seekers could be returned with a view to processing their claims. ${ }^{52}$

By establishing reception and screening capacities in line with EU standards, these neighbouring candidate states were intended to become 'safe third countries' for the purpose of pre-procedure returns of asylum seekers seeking protection in the EU, thereby widening the reach of 'protection elsewhere' policies. These policies were already a well-established response to the phenomenon of secondary movements that had been a core policy concern of European and other Western states since the $1980 \mathrm{~s}^{53}$ as similarly reflected in the objective of preventing intra-EU secondary movements in the various CEAS legislative instruments. ${ }^{54}$ At the same time, the pre-accession efforts put strong emphasis on 'flanking measures' that were meant to accompany the Dublin and Schengen Conventions so as to ensure external border controls sufficient to compensate the absence of internal border checks.

The historical background and the pre-accession process explain the way asylum seekers and refugees were received and perceived in most of the candidate states before their accession to the EU. First, and perhaps most importantly, asylum seekers were generally seen and treated as outright 'illegal' (rather than 'irregular') migrants (rather than people in potential need of international protection), as demonstrated by the priority given to detention of asylum seekers and illustrated by the general features of the detention centres in which they were often held for a considerable length of time. Second, the overriding concern in the new member states was that of avoiding the 'closed sack' effect, i.e., the fear of being the last stop for asylum seekers heading towards the western EU member states in their search for protection. ${ }^{55}$

This approach, in turn, influenced the policies and actual practices towards asylum seekers in some of the new member states. This was particularly clear in connection with the phenomenon of asylum seekers' secondary movements in that these member states appeared to be inclined to either prevent their entry in the first place or, if that strategy failed, facilitate their onwards movement towards western member states. For those asylum seekers whose applications were being examined on their merits, the outcome may have been affected by reminiscent Cold War antagonisms that in some instances appear to have significantly impacted the approach to assessing applications for international protection in some of the 'new asylum countries'. ${ }^{56}$ Unsurprisingly, the prototypical image of refugees intuitively first and foremost comprised persons resisting communist hegemony in the mould of the Hungarian uprising of 1956 and the

\footnotetext{
${ }^{51}$ For a general account of the pre-accession process and the subregional interactions, see Byrne, Noll and Vedsted-Hansen, supra note 5.

${ }^{52} \mathrm{Cf}$. Byrne, Noll and Vedsted-Hansen, supra note 4, at 371; N. Zaun, EU Asylum Policies. The Power of Strong Regulating States (2017), at 255-6.

${ }^{53}$ Cf. S. Legomsky, 'Secondary Refugee Movements and the Return of Asylum Seekers to Third Countries: The Meaning of Effective Protection', (2003) 15(4) International Journal of Refugee Law 567.

${ }^{54}$ See, in particular, recital 6 and Art. 36 of the Asylum Procedures Directive (Council Directive 2005/85, OJ 2005 L 326/13), providing for the notion of European 'super-safe' third countries. Although adopted only in December 2005, this Directive was based on a Commission proposal from October 2000 (COM(2000) 578 final) and an amended proposal from June 2002 $(\operatorname{COM}(2002) 326$ final).

${ }^{55}$ For a significant example see L. Sesickas et al., 'Lithuania', in Byrne, Noll and Vedsted-Hansen, supra note 5, 226, at 260-4; see also R. Byrne, 'Future Perspectives: Accession and Asylum in an Expanded European Union', ibid., at 383-91.

${ }^{56}$ See Sesickas et al., ibid., at 259.
} 
Prague Spring of 1968. Persons who did not correspond to that prototype might have difficulties in being recognized as in need of protection.

Thus, pre-accession capacity building focused mostly on border control and other restrictive measures, while the protective elements of the CEAS were given less priority. The shared experiences of many new member states have most likely been important factors in the creation of current subregional partnerships, in particular among the Visegrád states. These partnerships are playing an ever stronger and more visible role in the development and implementation of EU standards on reception, protection and integration of asylum seekers and refugees. The relative downplaying of refugee rights during accession must have been one critical factor in the Visegrád states joining forces to resist the EU Council Decisions on the controversial issue of relocation of asylum seekers to their territories. ${ }^{57}$

\subsection{Burden-shifting and insincere co-operation}

The perception of refugee protection as being subordinate to migration control is likely to have defined and framed the transposition and subsequent application of CEAS standards by new member states post-accession. Notably, the CEAS legislation had been developed and adopted by the EU-15 member states ahead of the EU enlargement by 1 May 2004, ${ }^{58}$ and thus presumably without any sense of ownership by the new member states in the first place.

The underlying objectives of the CEAS pointed towards the gradual creation of a rights-based protection system under the Amsterdam Treaty. ${ }^{59}$ Accordingly, the second phase of the EU asylum acquis was adopted during the transitional five-year period with relatively firm norms, although initially including a significant proportion of flexible standards, exceptions, and optional provisions, in particular on asylum procedures. ${ }^{60}$ This flexibility and the optional elements may have appeared attractive to the new member states, partly due to their legacy in terms of the rule of law and partly due to the perceived dominance of the migration control paradigm over refugee protection, as explored in Section 3.1.

As it turned out, however, the CEAS legislative instruments appear to have been programmed for implementation failures. ${ }^{61}$ With the CEAS lacking a burden-sharing component, it rather promoted burden-shifting behaviour. The Dublin system may have worked as a corroboration of the aforementioned 'closed sack' fear brought about by earlier bilateral readmission agreements, making not least the Visegrád states ultimately responsible for returned asylum seekers. The incomplete harmonization of substantive and procedural standards is likely to have been contributing to the development of weak and insufficient asylum systems in particular in new member states. And being weak on protection and integration of refugees must have seemed to be a reasonable antidote to being burdened by the Dublin system. If asylum seekers would perceive the new member states as unattractive, they would move on to other member states. This is exactly what happened.

Thus, the CEAS was characterized by structural failures or dichotomies in two different dimensions. First, even while coercive towards member states and rights-based in principle, the system did not effectively secure the rights of asylum seekers and refugees in practice, probably due to a combination of vague norms and limited efforts on the part of the Commission to enforce the

\footnotetext{
${ }^{57}$ See supra note 13

${ }^{58}$ The Asylum Procedures Directive (Council Directive 2005/85, OJ 2005 L 326/13), adopted on 1 December 2005, being the only exception. However, political consensus on the main provisions of the Directive was achieved in November 2004, cf. Council Doc. 14203/04 - ASILE 64, approved by the JHA Council on 19 November 2004.

${ }^{59} \mathrm{See}$, as the official initiator of the creation of the CEAS, Presidency Conclusions of the European Council held in Tampere 15-16 October 1999, paras. 10-27, especially paras. 13-17.

${ }^{60}$ Cf. J. Vedsted-Hansen, 'Common EU Standards on Asylum - Optional Harmonisation and Exclusive Procedures?', in E. Guild and P. Minderhoud (eds.), The First Decade of EU Migration and Asylum Law (2012), 255.

${ }^{61}$ Attempts were made to remedy this in the third phase asylum instruments adopted in 2011-2013, but these came too late and did not go far enough to prevent the crisis.
} 
implementation of these norms vis-à-vis member states. ${ }^{62}$ The coercive nature of the system can be and has indeed been criticized. ${ }^{63}$ Nonetheless, a system of coercion which is not being enforced with reasonable diligence is even more problematic inasmuch as the failure of enforcement can create or confirm the impression that formally binding norms are not really binding in actual practice.

Second, the CEAS has created, or at least reinforced, incentive structures that contributed to the inefficiency of the system itself. While the Dublin system has distributive effects due to its impact on the sharing of protection responsibilities and burdens among member states, these quantitative imbalances have gradually caused qualitative dysfunction of, in particular, the protective elements of the CEAS. As a result, we have seen tendencies to collapsing of asylum systems in certain member states and the consequent failure to respect the fundamental rights of the very same asylum seekers and refugees whom the CEAS was meant to protect, as somewhat reluctantly recognized by domestic as well as European courts. ${ }^{64}$ The gradual worsening of CEAS compliance was in turn exacerbated by the financial crisis which, in combination with political extremism fuelled by the crisis, obviously made it more difficult to remedy the problems. In some instances they became irresolvable and effectively resulted in collapsed asylum and border control systems for an extended period of time. ${ }^{65}$

Here, the CEAS-related rulings of the ECtHR and the CJEU come back in our story, with their perverse incentives for asylum seekers as well as member states not to act in accordance with prevailing CEAS standards. ${ }^{66}$ Thus, asylum seekers were de facto induced to escape dysfunctional asylum systems by way of secondary movements to other member states. In turn, member states in charge of such dysfunctional systems were rewarded for their failure to comply with the relevant CEAS standards due to the judicial protection of asylum seekers against being returned to those member states under the Dublin Regulation, hence reducing the relative protection burden of such member states.

Whereas the distributive aspects of the Dublin system played a crucial role in exacerbating the asylum crisis in southern member states, the dysfunctions of the CEAS are inextricably linked to the fact that the Dublin and Eurodac Regulations were adopted and entered into force earlier, and as far more complete regulatory instruments, than the CEAS legislation that was intended to harmonize the procedural and substantive standards on protection. Thus, the very premise of forcibly relocating asylum seekers to other member states under the Dublin system sits ill with the fact that the protective elements of the CEAS were developed gradually with rather vague standards set by the EU legislature, with incomplete implementation of these standards by a number of member states and with hesitant enforcement by the Commission.

\subsection{Accession and illiberal democracy}

Accession was an efficient way to short circuit the lengthy and contentious democratic processes that typically accompany refugee law reforms. Rather, EU technocrats and refugee law specialists, often with the participation of UNHCR and civil society actors, were able to transpose the complexities of the EU asylum acquis onto domestic law as part of the package deal for EU accession. If

\footnotetext{
${ }^{62}$ The Commission has apparently been aware of the need for more efficient enforcement of CEAS standards by way of systematic monitoring of member states' transposition, implementation and application in practice of these asylum standards, see the Commission Communication, A European Agenda on Migration, COM(2015) 240 final, 13 May 2015 , at 12.

${ }^{63} \mathrm{Cf}$. M. den Heijer, J. Rijpma and T. Spijkerboer, 'Coercion, prohibition, and great expectations: The continuing failure of the Common European Asylum System', (2016) 53 Common Market Law Review 607, at 608-15.

${ }^{64} \mathrm{Cf}$. the ECtHR and CJEU Judgments discussed in Section 2.2 at supra note 36; for an analysis see J. Vedsted-Hansen, 'Reception Conditions as Human Rights: Pan-European Standard or Systemic Deficiencies?', in V. Chetail, P. De Bruycker and F. Maiani (eds.), Reforming the Common European Asylum System: The New European Refugee Law (2015), 317.

${ }^{65} \mathrm{On}$ the interaction between the financial crisis and the asylum crisis, see Section 2.3 with reference to Trauner, supra note 38 , at 311 .

${ }^{66}$ See den Heijer, Rijpma and Spijkerboer, supra note 63, at 614.
} 
so desired, the resulting asylum laws and practices that flowed from it could easily be cast as a project of transnational elites.

As we noted back in 2004, the old member states were likely to lose much of their bargaining power $v i s$ - $a$-vis the new member states once the latter had acceded to the EU. ${ }^{67}$ The foreseeable shift in the various member states' relative influence upon accession was not the only factor posing challenges to the future protection capacity of the new member states. In addition, we argued, the accession process had been directed by a tunnel vision that was focused on the transfer of the first phase of the EU asylum acquis to the new member states.

The realization of this vision was institutionalized by way of the so-called 'twinning projects' through which certain member states undertook capacity building measures in candidate states in preparation of their EU accession. While often framed as co-operation on migration control and management, some of these projects included extensive support for the introduction and implementation of asylum legislation in candidate states, sometimes also involving the UNHCR and IOM in consultative or similar roles. ${ }^{68}$ The protection capacities that were created in candidate states under these co-operative programmes were in all likelihood significant. At the same time, such approaches may have contributed to creating rather narrow segments of administrative and judicial officials in new member states who became familiar with the EU asylum acquis as part of the legal capacity building. In other words, it could be argued that 'asylum expert elites' of the western member states were contributing to the creation of similar elites and institutionalized doctrine' in new member states. ${ }^{69}$ Due to the hierarchical aspects of such 'twinning', this form of capacity building may have contributed to the rather limited effects of the normative transfer of the asylum acquis that appeared after the EU accession. In any event, the capacity building endeavours may have created some basis for the pre-understanding that the then existing first phase EU asylum standards were adequate and sufficient for the new member states.

Nonetheless, during the preparations for enlargement the EU was already in the process of reforming these asylum standards pursuant to the Amsterdam Treaty. The new member states may therefore have been sceptical towards yet another request by the old EU member states for amending or remodelling their domestic asylum legislation. ${ }^{70}$ Consequently, if the new member states during their candidacy for EU membership had felt little if any ownership to the emerging EU asylum acquis that was essentially imposed upon them as a prerequisite to accession, they were likely to be even less committed to implementing the second phase of EU asylum instruments that were adopted at the time of accession.

\subsection{Conclusion}

The imposition of EU legal standards in the accession process, together with the historical tradeoff between refugee protection and migration control, was most likely reinforced by subregional processes and interactions. Being at the receiving end of subregional as well as of supranational norm-making without much of a voice of their own characterized the pre-accession experience of new member states and threw its long shadow into the present. It is reasonable to conclude that this has contributed to the insufficiency of their asylum and reception infrastructures as well as their political rejection of the regulatory structures and principles upon which the CEAS rests. With the crisis, the tables have been turned, and the peripheral member states, most of all the Visegrád states, assume centre ground in the making of constitutional politics.

\footnotetext{
${ }^{67}$ See Byrne, Noll and Vedsted-Hansen, supra note 4, at 371-2.

${ }^{68}$ See Byrne, Noll and Vedsted-Hansen, supra note 5, at 16-17; on co-operation between Germany and Poland and the Czech Republic see Noll, 'Germany', ibid., 29, at 41-7; on Nordic-Baltic co-operation see Vedsted-Hansen, 'Nordic Policy Responses to the Baltic Asylum Challenge', ibid., 203, at 218-22.

${ }^{69}$ Cf. R. Cotterrell, 'What Is Transnational Law?', (2012) 37 Law \& Social Inquiry 500, at 508; on Cotterrell's theory on transnational law see below Section 5.2; see also Zaun, supra note 52, at 230-1.

${ }^{70}$ See Byrne, Noll and Vedsted-Hansen, supra note 4, at 371.
} 


\section{Three crisis factors}

Our cross-cutting analysis of the 2015 crisis has shown that it was enabled by three factors. First, through a historical prism, the antecedents to the current disdain for the EU refugee protection architecture can be seen in the early 1990s. Hard law was created in the area of asylum in conjunction with border control (the Schengen and Dublin Conventions), whereas refugee rights and protection were relegated to the realm of soft law. In the accession process, the normative emphasis on border control was very strong, while the normative emphasis on refugee protection was weak, sending the message to acceding states that protection measures were dispensable obligations. Transposing the asylum acquis meant imposing the terms of how the new member states would admit and receive migrants, instrumentalizing international refugee law. Asylum law norms were, and remain, 'flanking measures' that enable the abolishing of internal border controls. It was quite evident that free movement across borders would be challenged by governments when a significant number of unchecked secondary movements of asylum seekers were to occur within the EU, as has happened since 2015.

Second, even today's open defiance of EU law by member states is explainable if one considers the implications of EU norms on core versus peripheral states and the patterns of resistance to the CEAS that were gradually worsening between 2004 and 2015. The scepticism of frontline states towards the intents and unequal effects of 'protection elsewhere' and asylum acquis was reinforced by Brussels' laissez-faire policy on the violation of protection norms in the South and the East of the EU. Strategies of resistance by frontline states of this crisis were tutored in the prior experience of thwarted Dublin removals. When other member states suspended Dublin removals to states such as Greece and Hungary, often at the behest of well-meaning courts, those violating the law were rewarded for their behaviour with a shifting of their share of the protection burden elsewhere. The violation of CEAS norms attained such a magnitude that their 'flanking' function for the upholding of internal free movement crumbled. The EU regional asylum framework was readily undermined by states relying upon 'self-help' with their attention on subregional migration across borders and recourse to bilateral readmission treaties.

Third, the current populist threat to democratic decision-making emerging in Hungary and Poland and moving on to the West and South has a prehistory as well. The lived experience of grassroots voters in frontline receiving communities would hardly incline them to turn to Brussels, the core of the EU, to assume obligations and await promised 'solidarity' for the reception of refugees. The Visegrád states acceding to the EU will have understood that external border control would be far more important than refugee protection - a message that had been valid all the way throughout their past as Warsaw Pact members. Also, the development in the East of the EU gets sharper contours once we consider how the Visegrád states were excluded from laying the foundations of CEAS, yet included in underwriting of the Dublin system. The trajectory that the nascent populism of the early 1990s would later take was not on the radar of asylum scholars during this period, as they did not realize the potential political success of these movements nor the full implications of an exclusionary nationalism that was to reject immigrants, refugees, and more fundamentally the core democratic values of the EU. The roots of populism's current rise in the Visegrád states were highly visible to observers of the region post-1989, and well before the accession process was in full swing. ${ }^{71}$

\footnotetext{
${ }^{71}$ As Mudde and Kaltwasser observe in Poland, Hungary, and then, Czechoslovakia, it was during this period of transitional elections that populist sentiments were particularly strong in representing 'the people' against the 'elites' whose interests were represented during the decades of communist rule. While many of the parties dissolved, the rhetoric of a 'stolen revolution' remained alongside allegations against the new 'democratic' elites. C. Mudde and C. R. Kaltwasser, A Very Short Introduction to Populism (2017), at 37.
} 


\section{Conclusion: A crisis of method?}

An explanation to the ongoing crisis needs to be sought outside of the body of supervening law (such as the CEAS and the 1951 Convention). The defects of the CEAS are well known at this stage, but they are in themselves insufficient to explain its rapid disintegration. To understand the crisis, we had to look both inside and beyond that body of law and place it in its wider political-historical context.

A failure to do so accounts for the weakness of refugee law scholarship when confronting the crisis. Much of it is still performed within a methodological framing at a distance from the broader disciplinary developments within international law. Grounded within the complex framework of EU legislation, EU refugee law in particular is commonly viewed through the prism of vertical hierarchies that fail to capture the dynamics that influence law and outcomes from below. This central constraint reduces the capability to fully engage with the historical significance of the 2004 EU enlargement for the systemic crisis of refugee protection that unfolded in 2015. We therefore propose that refugee law scholarship should engage to a greater extent with international law in history and with transnational legal developments. In the following discussion, we will explain the potential of each of these two methodological approaches for refugee law.

\subsection{Learning from law in history}

To understand the unravelling of European norms, our focus has to be on the past at work in the present crisis of law. In the prior two decades, international legal scholarship has engaged in a 'turn to history'. ${ }^{72}$ The turn does not imply that we are remaking ourselves as historians, but rather that we, as legal scholars, maintain a sensitivity to the history that law has taken part in producing. ${ }^{73}$ It seeks to study law from within law, emphasizing the synaptic connections between law and the world with which it interacts. But it goes beyond the established modes of historicizing that refugee lawyers employ, usually to support an interpretive argument, to introduce to a text culminating in an analysis of valid law, or to write a traditional legal history of an aspect of refugee law. ${ }^{74}$

The turn to history within international law seemed to have gone largely under the radar of refugee law scholars. B. S. Chimni, the eminent public international and refugee lawyer, is one of the few exceptions to that rule. ${ }^{75}$ In his writings, he has brought methodological advances and novel perspectives from international law scholarship into refugee legal thinking. It is indicative,

\footnotetext{
${ }^{72}$ There is a comprehensive literature reflecting the turn to history. M. Koskenniemi's The Gentle Civilizer of Nations. The Rise and Fall of International Law 1870-1960 (2002) is performing this turn and has concurrently made it visible to a wider international law community. A Journal of the History of International Law, edited by international law scholars (rather than historians) has been published since 1999. The publication of B. Fassbender and A. Peters, Oxford Handbook on the History of International Law (2012) as well as of 13 chapters on historical dimensions of international legal theory in A. Orford and F. Hoffmann, Oxford Handbook of the Theory of International Law (2016) are further signs of the turn's perseverance. M. Bak Mckenna and M. Arvidsson, 'The Turn to History in International Law and the Sources Doctrine: Disruption, Democratization and Distress', (2019) 31 Leiden Journal of International Law 37 is a recent example.

${ }^{73}$ M. Craven, 'Introduction: International Law and Its Histories', in M. Craven, M. Fitzmaurice and M. Vogatzi (eds.), Time, History and International Law (2007), 1 at 7.

${ }^{74} \mathrm{We}$ have performed a search of the term 'history' in IJRL issues available online and reviewed the top 60 hits. Focusing on articles and editorials, the vast majority fall into either of the three traditional uses. For an example of the first type see G. Goodwin-Gill, 'The Dynamic of International Refugee Law', (2013) 25 International Journal of Refugee Law 651. For an example of the second type see C. Baillet, 'Examining Sexual Violence in the Military within the Context of Eritrean Asylum Claims Presented in Norway', (2007) 19 International Journal of Refugee Law 47. For an example of the third type see R. Karatani, 'How History Separated Refugee and Migrant Regimes: In Search of their Institutional Origins', (2005) 17 International Journal of Refugee Law 517.

${ }^{75}$ For two other exceptions see K. B. Sandvik, 'A Legal History: The Emergence of the African Resettlement Candidate in International Refugee Management', (2010) 22 International Journal of Refugee Law 20; B. Schotel, 'Legal Protection as Competition for Jurisdiction: The Case of Refugee Protection through Law in the Past and at Present', (2018) 31 LJIL 9.
} 
though, that these texts have been published in the interdisciplinary Journal of Refugee Studies and the Refugee Survey Quarterly ${ }^{76}$ rather than in journals focusing on refugee law qua law. That Chimni also is a central protagonist in the emergence of TWAIL and its analysis of power imbalances in law, is no coincidence. TWAIL researchers trace the role of international law in creating and maintaining differences between the North and the South on a global scale. The same optics can be applied to regional rather than global differences, as those within the European Union where in joining the EU, the accession member states have been confronted with rules made by the Centre. ${ }^{77}$ In the distribution of responsibilities for refugees within the EU, the Visegrád states might be inclined to see the EU and its member states divided into the 'norm makers' and presumed 'norm takers'. While TWAIL researchers focus on the history of Northern domination being encoded into the DNA of international law, European legal researchers might be well-advised to look at the CEAS in a similar way. As the newly decolonized states were relative newcomers to the international system in the 1960s, so were the newly admitted member states in relation to EU law and the CEAS. In the course of both integration processes, the racial coding of migrants from the new partner states changed, but racialization as such certainly did not come to an end. ${ }^{78}$ When borders move, exclusion moves on to new groups, but patterns of exclusion remain. And in both cases, a normative straitjacket was in place that limited the power of newcomers.

Chimni's work helps us think about today's conflicts through its antecedents. His 1998 article tracks how the refugee crisis of the 1980s led to a schismatic moment in refugee law scholarship. That crisis was essentially about refugees from the less affluent South starting to appear in the more affluent North. Dubbed as 'the new asylum seekers' at the time, Chimni thinks that traditional 'positivist' refugee law academics and a group of scholars adhering to a 'new approach' both agreed on the 'founding myth of difference' between that group and the old intra-European Cold War asylum seekers. ${ }^{79}$ However, the 'positivists' continued to invoke the 1951 Convention with respect to these new asylum seekers, while the adherents of the new approach articulated a set of policy proposals which justified restrictive measures. The proposals included the rejection of the exilic bias of international refugee law; a nearly sole reliance of the solution of voluntary repatriation; and an emphasis on the responsibility of the state of physical origin. ${ }^{80}$

As we now are faced with yet another crisis, it helps to recall how the cleavage emerging in the 1990s affected the substance of refugee law and refugee law scholarship simultaneously. It reminds us that the task of scholarship in crisis is not to scramble to ersatz policy-making, but to provide a more nuanced understanding of the crisis and the conditions that made it possible.

Centre-periphery relations in the making and unmaking of law, mostly between pre-2004 EU Members and Poland, the Czech Republic, Slovakia, and Hungary, proved to be pivotal for our analysis. The Visegrád Group's positions today are informed by its historical experience at the receiving end of a number of international law instruments. They were the objects rather than the subjects of the Versailles Treaty (1919), the Treaty of Munich (1938), and the Declaration of Yalta (1945). In the accession process, the Visegrád states were again the objects of law-making: transposing the asylum acquis meant imposing how the new member states would admit and receive migrants, instrumentalizing international refugee law. By creating the new asylum states on the frontiers of an expanded EU, a buffer against unwanted migration for old member states

\footnotetext{
${ }^{76}$ B. S. Chimni, 'The Geopolitics of Refugee Studies: A View from the South', (1998) 11 Journal of Refugee Studies 350; B. S. Chimni, 'Globalization, Humanitarianism and the Erosion of Refugee Protection', (2000) 13 Journal of Refugee Studies 243; B. S. Chimni, 'From Resettlement to Involuntary Repatriation: Towards a Critical History of Durable Solutions to Refugee Problems', (2004) 23 Refugee Survey Quarterly 55.

${ }^{77}$ J. Reynolds, 'Peripheral Parallels? Europe's Edges and the World of Bandung', in L. Eslava, M. Fakhri and V. Nesiah (eds.), Bandung, Global History, and International Law: Critical Pasts and Pending Futures (2017), 247, analyses the contemporary relations between Greece and economically central EU member states in this vein at 258.

${ }^{78}$ The emergence of the Polish plumber in Brexit discourse is but one example.

${ }^{79}$ See Chimni, supra note 9, at 368-9.

${ }^{80}$ Ibid., at 369 .
} 
was established. The current resistance to international and EU legal obligations towards refugees by the Visegrád states is an outcome of this experience.

There is yet another layer as one historical phase produces its echoes in a subsequent phase. The recognition of borders resulting from the Second World War and their rigid defence against any category of trespasser was an important topos for the Soviet Union and its satellites throughout the Cold War, reflected inter alia in the border control obligation in Article 5 of the 1955 Warsaw Pact $^{81}$ and in domestic laws. ${ }^{82}$ This gave the survival fears of pre-war Central Europe states a second lease of life in the Europe of the Iron Curtain. Perhaps no other international law instrument illustrates this better than the Helsinki Accord of 1975, an important soft law instrument of West-East detente signed by 35 states. The Accord confirmed the inviolability of borders, which the Soviet Union saw as a major negotiation victory, well worth concessions in fields such as human rights and the freedom of movement. But '[b]y agreeing to the West's terms on [human rights] in Helsinki [the Soviets] unwittingly compromised' their position that the forcible repression of dissidents was wholly within their domestic jurisdiction. ${ }^{83}$ 'Eastern European diplomats warned their Soviet counterparts not to take the gamble, but the Soviets were desperate for a settlement and failed to foresee its implications' ${ }^{84}$ Dissident movements in Moscow, East Berlin, Budapest, and other Eastern Bloc capitals seized the opportunity, and references to the Helsinki Accord's human rights provisions soon underpinned their challenges to autocracy in the years following the Accord.

The Helsinki Accord contained freedom of movement language under a humanitarian heading ${ }^{85}$, but lacked all references to refugee protection. The historical experience of dissent in Central and Eastern Europe tied human rights and freedom of movement to the dissolution of state socialism and one-party rule, while the inflow of refugees seeking protection was a nonissue until 1989. In 1975, even the West saw human rights and refugee law as two distinct fields separated from each other. This was, after all, well before Article 3 of the 1984 CAT and before the Soering judgment of 1989. In the political imaginary of East-West negotiations, freedom of movement was strongly associated with the right to leave any country, including one's own. Any mention of asylum would have been a bad negotiation strategy, evoking the ideological rift between communism and capitalism. And, as the dissident experience suggests, human rights were predominantly a means to challenge the dictatorship of the one-party system that dominated one's own country. Their linkage to the protection of refugees was a relatively marginal issue in the Cold War experience of the Visegrád states. While Western Europe saw ever tighter linkages evolving between refugee protection and human rights, they remained at a distance from each other in Central and Eastern Europe. This engendered a particular constellation where human rights were largely absorbed into the history of liberation from hegemonically imposed rule, while border control remains a constant and is rigidly linked to state survival.

\subsection{Beyond the hierarchical approach to refugee law scholarship}

EU refugee law scholarship tends to assume a framing of the law that emphasizes hierarchy. Analytically, the main focus is on the conformity of single norms or single laws with supervening international refugee law and international human rights law. There is less interest in norms

\footnotetext{
${ }^{81}$ See text accompanying note 49 above.

${ }^{82}$ See, e.g., the Law on the State Border of the German Democratic Republic of 25 March 1982, with its preamble making an explicit reference to the inviolability of borders as a principle of international law. Gesetz über die Staatsgrenze der Deutschen Demokratischen Republik vom 25. März 1982, Gesetzblatt der Deutschen Demokratischen Republik (1982), 197.

${ }^{83}$ A. Preston, 'Heresy from Lesser Voices', (2019) 41(12) London Review of Books 17, at 18.

${ }^{84} \mathrm{Ibid}$.

${ }^{85}$ The Accord's Section 6 on 'Cooperation in other areas' contains sub-sections on the 'Promotion of tourism' and the 'Economic and social aspects of migrant labour'. The section on 'Co-operation in Humanitarian and Other Fields' features a sub-section on 'Human Contacts'.
} 
cropping up from domestic law, bilateral and subregional processes, as long as they are not identified as 'best practice'. Due to the focus on single norms and EU institutions, massive implementation problems at the domestic level are seen as violations to be rectified by the Commission and the European Courts, but not necessarily as a nucleus of law-making from below. It is generally assumed that more international refugee law, international human rights law and EU law and more adjudicative institutions are overall a good thing - and a suitable remedy for massive implementation problems.

To the extent refugee law scholars participating in this approach think of themselves as positivists, that would be open to question. The domestic, bilateral and subregional norm-making that crops up from below may be as much 'positive' as the supervening international law that is at the centre of the profession's attention. Rather, this entrenched hierarchical perspective obscures many complicating factors that are essential to understand the turning points in history of which crisis is a sign.

In order to capture what moves, makes and breaks the law, we should understand the law as a transnational phenomenon. Transnational law is known to encompass, in Philip Jessup's formulation, 'all law which considers actions or events that transcend national frontiers', ${ }^{86}$ thus bypassing traditional separations into domestic, foreign and international law, as well as public and private law. Transnational law prepares us to see a complex web of legal relations brought about by varying constellations of actors. ${ }^{87}$ It does so by emphasizing the lateral over the vertical. The standard approach within EU refugee law ever so often perceives domestic law and practices as troublemakers to be put in place by norms of higher order. Transnational law, however, enables us to defer the judgment until a later point in time when a fuller picture has emerged. In our text, we adopt this approach for explanatory purposes by looking beyond EU institutions and the law they hand down to member states. Our analysis has emphasized how subversive domestic law may be in the long run, and it highlights the bilateral relations and subregional groupings that make these forms of recalcitrant law intelligible.

Transnational law, however, means many things to many scholars. ${ }^{88}$ Our version of transnational law reflects an understanding that Roger Cotterrell has traced in a 2012 review essay. ${ }^{89}$ Cotterrell puts the 'institutionalization of rules through established practices of managing them' into the centre. Beyond rules, Cotterrell admits a wider range of normative ideas to what he calls 'institutionalized doctrine'. ${ }^{90} \mathrm{He}$ goes on to ask: 'why not recognize that agencies for making, interpreting, or enforcing law do not necessarily depend on rules? As Max Weber ... famously showed, the authoritative practice of such agencies can be based instead, in some circumstances, on tradition or charisma'. ${ }^{91}$ Why not, indeed?

Cotterrell's approach to transnational law allows us to factor the multifaceted dimensions of historical experience into our observations on the making and breaking of refugee law in Europe. Domestic lawbreaking in newly admitted member states evolved into a remaking of law at the European level. In our account of the forces at play at the meta-level of European refugee law,

\footnotetext{
${ }^{86}$ This is a phrase from the often quoted passage from P. C. Jessup, Transnational Law(1956) which provides a historical frame to the enterprise of transnational law.

${ }^{87}$ To describe the relationship of international law, EU law and domestic law, Daniel Bethlehem used the metaphor of 'a web, or a net made up of numerous strands criss-crossing at various points while, at the same time, going in different directions'. D. Bethlehem, 'International Law, European Community Law, National Law: Three Systems in Search of a Framework. Systemic Relativity in the Interaction of Law in the European Union', in M. Koskenniemi (ed.), International Law Aspects of the European Union (1998), 195.

${ }^{88}$ In recent years, a number of publications have adopted a transnational law perspective when analysing the EU and its laws. See, inter alia, M. Maduro, K. Tuori and S. Sankari (eds.), Transnational Law: Rethinking European Law and Legal Thinking (2014); M. Avbeli, The European Union under Transnational Law: A Pluralist Appraisal (2018).

${ }^{89}$ See Cotterrell, supra note 69.

${ }^{90}$ Ibid., at 504 .

${ }^{91}$ Ibid., at 508 .
} 
we learned that certain norms - written and unwritten - were and are given more attention than others. Through this optic, we recognize that low-level norms at domestic level start to resonate with high-level norms on supranational and international level in a way that traditional refugee law denies us. With this method, the current crisis presents itself as a turning point for refugee protection as well as for the foundational principles of EU law.

\subsection{Methodological enlargement}

Looking back at the entirety of our argument in this article, it becomes clear that the three crisis factors identified in this article became visible only because our analysis brought together valid law with its historical and transnational conditionalities. We argued that the formative structures of the asylum crisis, dating back to the 1990s, prioritized border control (summarized as the first crisis factor in Section 4). A fuller historical analysis in the current section indicates that these antecedents stretch back to the end of the First World War. The continuity of border-control thinking over the longue durée is humbling; the challenge of undoing the crisis is commensurate to its length and depth. We also highlighted the destructive interplay between EU core and periphery, with states providing sub-standard protection being rewarded with a de-facto reduction of protection obligations (the second crisis factor). This insight shows how productive a sustained transnational analysis of the law can be. It could be taken even further by integrating within it questions relating to the political economy of enlargement. We would find a parallel development where enlargement downgraded asylum law standards and practices and imposed 'severe limitations to the enactment of EU social citizenship' as well. ${ }^{92}$ Otherwise put, enlargement was a rollback both for the rights of insiders and of outsiders, suggesting that we are dealing with more than a row of errors in policy-making. ${ }^{93}$ Finally, we were able to show that the periphery of accession states was excluded from the foundational lawmaking by the centre, reinforcing populist-style critiques of elitism and legitimizing burden shirking in the periphery (the third crisis factor). In this latter pattern, we find that the transnational making and breaking of law and the historical analysis of persistent dysfunctionalities come together, suggesting that the crisis is indeed constitutional in nature.

It is only by questioning its own traditions that refugee law scholarship may retain its relevance in times of crisis. In this article, we have moved beyond the hierarchical approach to refugee law scholarship to focus on the history at work in the present crisis of law and to track how international and European law was in part undermined and modified by a transnational law from below. We have done so to illustrate the relevance of wider methodological debates in contemporary international law for the analysis of EU developments. An analogous widening of methodological repertoires can also be observed in explorations of asylum underway in other disciplines as well. ${ }^{94}$ We believe that refugee law scholarship has everything to win from becoming part of those discussions and taking inspiration from the methods they offer.

\footnotetext{
${ }^{92}$ B. Likic-Brboric, 'EU Enlargement, Migration, and Asymmetric Citizenship: Political Economy of Inequality and the Demise of the European Social Model?', (2011) 8 Globalizations 277. There would be merit in linking back the political economy of EU enlargement to the economic as it figures in TWAIL and its theoretical sources.

${ }^{93}$ In this article, we are unable to give the link between economics, policy, and law its full due. However, the question how economic meta-norms are enacted in law is decisive for TWAIL thinkers such as B. S. Chimni. When projecting TWAIL onto centre-periphery relations within the $\mathrm{EU}$, this is a question that acquires a tantamount role.

${ }^{94}$ See, e.g., the way international relations branched out into securitization studies, featuring a broader array of disciplinary practices indebted to critical thinking. For a seminal example in the field of EU migration law see J. Huysmans, 'The European Union and the Securitization of the Migrant', (2000), 38 Journal of Common Market Studies 751.
} 